\title{
Consumer Assessment of the Quality of Transport Services and Guidelines to Increase Their Competitiveness
}

\section{Daniel Yordanov*}

\section{Abstract}

One of the conditions for the successful functioning of transport companies is that the latter should maintain and increase certain levels of competitiveness. Most small transport companies should try to find their own market niche for protecting themselves from competition. To this effect, the providers of such services should seek to offer are unique and different from competitors' services.

This paper tries to give an answer the question as to what has the greatest impact on consumers when deciding on the choice of the carrier. The proposed solutions will help transport companies in the formulation and development of competitive strategies. The analysis was carried out on the basis of the results of a questionnaire study conducted in Bulgaria, examining the degree of satisfaction of users of transport services

Key words: transport services, competitiveness, Consumer assessment

JEL: D22, L26, L90

\section{Introduction}

In scientific literature, there are many definitions of the essence of competitiveness, and the phenomenon is considered at different levels - national, regional, sectoral, corporate product. The work of a number of economists is the basis of the modern concept of competitiveness. We will mention only the most popular names in the field: A. Smith, D. Ricardo, D. Mill, J. Robinson, John. M. Keynes, Schumpeter, P. Heine, F. Hayek, F. Knight, K. McConnell, S. Brew, M. Porter (Porter 1996, Mc Connell. 2011).

The basics of this concept can be attributed to the assumption of A. Smith (1933, p. 329) that "...In general, if any branch of trade, or any division of labour, be advantageous to the public, the free and more general the competition, it will always be the more so". Economists from the neo-classical schools D. Ricardo, J. Mill and others further developed A. Smith's thesis of competition. The main forms of contemporary competition are as follows: perfect competition, oligopoly and monopoly. Subsequently competition was understood as J.M. Keynes defined perfect competition, namely as "a situation in which a single seller cannot influence price" just in terms of demand. Thus, perfect competition is "a situation in which a single seller cannot make more than normal profits" (Robinson 1933). The contemporary importance of competition is presented by M. Porter (1988). However, Porter (1996) connected competition with the ability to freely enter or 


\section{Articles}

exit the market. Hence in his opinion profitable markets yield high returns and they will attract new entities. Unless the entry of new entities can be blocked by incumbents, the abnormal profit rate will trend towards zero (perfect-competition). Porter develops the concept of competitive advantage by defining that the basis of competitive advantage is specialization (Warf, Stutz 2007).

Velev (2009) gives the following definition of competitiveness: "competitiveness of an enterprise is its ability to create and sustain competitive advantages that lead to high results of doing business in the long term through constant updating and improvement ".

Improving the competitiveness of an individual transport company is a necessary condition for its successful functioning in a market economy. Unless constant efforts are made to improve competitiveness, the company risks being left without access to the transport market, which will eventually lead to its bankruptcy. Competitiveness is characterized by the requirement to achieve higher productivity, increase real incomes and improve living standards.

Most small transport companies and individual carriers are trying to find a niche market where they will be somewhat protected from competition. To achieve this goal, they should provide services which in some cases are unique and different from competitors.

According to lliev (2011, p.453), "leading in the understanding of competitiveness is the creation and acquisition of strong and protected competitive advantages of the company in comparison with other participants of the relevant target market of products ". In assessing its competitiveness, the transport company should first determine: its main competitors; their strengths and weaknesses; geographical location; share of the total volume of the transport market (services) in the region; the volume and range of services;
Consumer Assessment of the Quality of Transport Services and Guidelines to Increase Their Competitiveness

additional services; prices and pricing; the presence of competitors' opportunities to increase and expand their capabilities and prospects, etc.

Gathering information about competitors is quite a challenge. A certain role in this respect is played by the study of commercial and advertising materials, financial condition (if possible), but often the necessary information can be obtained from customers who maintain relationships with competitors.

For transport companies it is advisable that they should analyze the extent to which their services, compared to the requirements of competitors, meet customers' requirements, safeguards, terms in delivery technology, fare levels, as well as the important reasons why customers selecting alternative services, etc.

Estimation the level of their competitiveness is not a requirement for best business practices but it will help the transport entrepreneur to secure the market position on the fully competitive market. In addition, the entrepreneurial behavior should be as reaction on the competitors' market behavior as "competitive advantage is based more on intelligence than on owned assets and capital" and the last two are a necessity, but not enough to attract a well-informed client." (Velikova, 2008)

The competitiveness of a transport enterprise can be assessed only among enterprises belonging to the same industry or producing the same goods and services. The competitiveness of the transport enterprise depends largely on how far the enterprise can adapt to the changing conditions of competition in the market.

Competitive advantages lie in any component of the commercial transport offer and not only in the cost and quality of the services offered. Characteristics of the competitiveness of the product for the industry are discussed in detail by Sterev 


\section{Articles}

(2014). In any case, in today's market, the required level of quality and low cost can only be the "price of participation in the game", so transport companies are obliged to provide the customer with something else that will make them preferable.

Competitiveness of transport services is expressed in their ability to meet the requirements of the quality of the competitive market and to satisfy the needs and requirements of consumers. "Satisfied customers represent a huge competitive advantage for the enterprise, as they are the main source of referrals, such as: to tell their close - potential customers about their positive experience, to express an opinion in the form of constructive criticism or praise" (Velikova 2011). For taking competitive advantages transport companies must constantly make efforts to improve their competitiveness, and this, in turn, is associated with the price of many costs - marketing, new technologies, new vehicles, innovations, etc.

A systematic study of the needs of individual shippers and the population of transportation can contribute to a very high degree to improving the competitiveness and quality of transport services (Gatovsky 2017, p. 247).

\section{Statement and results of the conducted research}

This article presents the results of a study related to the degree of satisfaction of users of transport services, which also examined their main criteria when choosing a transport company.

Our goal is to answer what the main criteria are of the users of transport services when choosing a carrier, how many Bulgarian automobile enterprises engaged in the transportation of goods meet the demand for the quality of the competitive market and to what extent they meet consumer needs and requirements.

In order to take a firm foothold in the competitive market, transport automobile companies should constantly make efforts to improve their competitiveness. Thanks to the main results of the study, an attempt will be made to come up with specific recommendations to vehicles in terms of market demands.

The study is experimental and is applied to users of services of the automobile enterprises offering freight transportations.

\section{The choice of objects for study}

As the individuals and industry could use their own transport or to outsource it, it is quite difficult to find out the exact number of users of transport services. On this basis, the survey of 140 users can be accepted as an adequate and sufficient representative for the study.

Two main principles were used in data collection:

- The principle of random selection;

- The principle of independent choice.

Data processing and analysis were carried out in 140 observations distributed in the following sectors of the Bulgarian economy. Some $21.4 \%$ of the surveyed users of transport services develop their activities in the field of agriculture, $7.1 \%$ - in the mining industry, $35.7 \%$ are engaged in manufacturing activities, $3.6 \%$ - in the energy business, $7.1 \%$ the construction business, $10.7 \%$ of the trade and forwarding business and $3.6 \%$ are engaged in other business different from the abovementioned. 


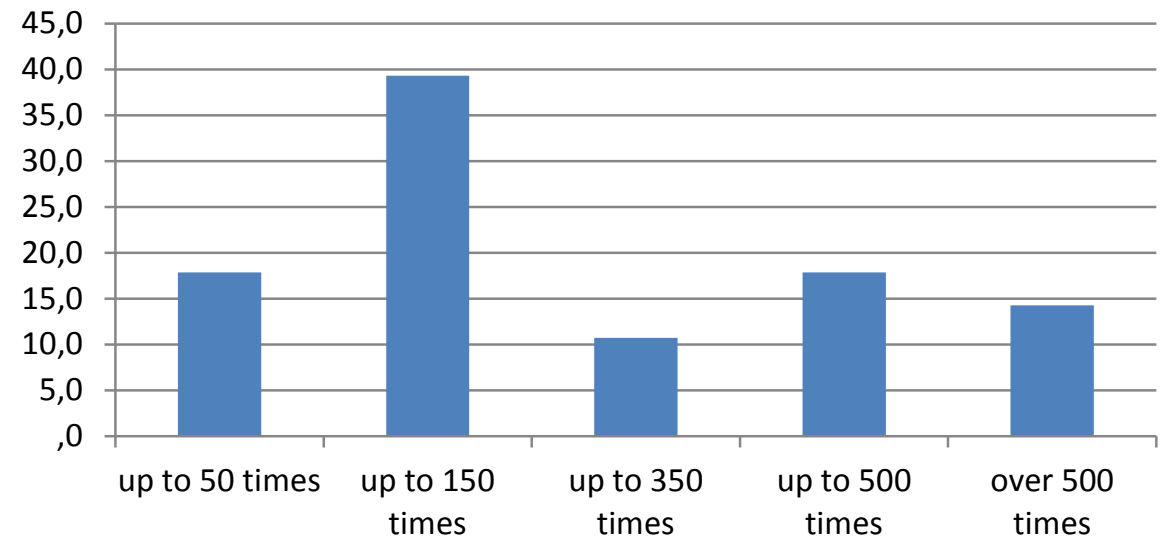

Figure 1. Distribution of respondents by frequency of transport services used.

The surveyed users of transport services in terms of frequency of use of transport outsource service are summarized next:

- the largest number of surveyed users $39.3 \%$ - use transport services up to 150 times annually,

- $17.9 \%$ of surveyed users use up to 50 times annually,

- $17.9 \%$ use transport services up to 500 times a year

- $10.7 \%$ use transport services up to 350 times a year, and

- $14.3 \%$ more than 500 times.

Figure 1 shows the percentage distribution of the frequency of use of transport services by surveyed users.

\section{Impacts of the services on transport}

Of the surveyed users - $42.9 \%$ transferred an average annual to 100 tons for transportation, $35.7 \%$ to 1000 tons for transportation, $10.7 \%$ transferred up to 30 tons, and $10.7 \%$ exceeded 1000 tons.

Thus, we can say that this study covers a wide range of users of transport services, both in terms of the scope of activities, the frequency of use of transport services and the number of goods transported. This suggests that it is possible to draw the right conclusions and make specific recommendations on the basis of the results.

\section{Analysis of results}

In the study transport users had to answer several groups of questions about their level of satisfaction based on certain quality indicators. As a result of the study, the results presented below were observed.

The first group of questions is related to the extent to which users of transport services were satisfied with the service of the transport company for the last 12 months - for the following quality parameters:

- Schedule and delivery time;

- Compliance with the schedule and terms of transportation;

- Connectivity to other modes of transport and use of terminals;

- The adoption of adequate measures by transport companies when it is impossible to carry out the agreed transport.

The analysis of the answers received in the survey allows us to make the following conclusion:

Concerning the proposed schedule and time for transportation, to a large extent carriers offer the appropriate schedule and time for transportation - more than $85 \%$ of 


\section{Articles}

consumers were satisfied and about 14\% were dissatisfied with the proposed schedule and delivery times. In the performance of the shipment itself, there was an increase in rather negative responses, indicating that to some extent the carriers were not complying with their obligations - $50 \%$ were quite satisfied, $10,7 \%$ were quite dissatisfied, and $14.3 \%$ did not answer the question. How positively can it be explained that to a large extent carriers take adequate measures for consumers when they cannot perform the agreed transport only $7.2 \%$ of users of transport services are dissatisfied. In general, a small number of users (39.3\%) are interested in the proposed possibilities of communication with other modes of transport and the use of terminals when choosing a carrier.

The second group of questions is related to the extent to which the users of transport services are satisfied with what is used during the transport of transport equipment and vehicles over the last 12 months with respect to the following parameters:

- Ability to request the necessary vehicles; - Availability of necessary equipment and specialized vehicles;

- Availability of information necessary for the transport of equipment and vehicles;

- Reliable and timely provision of necessary equipment and vehicles;

- Cleanliness and physical/technical condition of the provided equipment and vehicles during transportation;

- Actions to change equipment and vehicles if they do not meet the needs of users.

According to users of transport services, most carriers have the necessary vehicles and equipment and largely meet their requirements. More than $85 \%$ of users of transport services were largely satisfied with the ability to request the necessary vehicles, more than $78.6 \%$ were satisfied with the availability of carriers of the necessary equipment and specialized vehicles. Only $10.7 \%$ of carriers did not have the necessary equipment and specialized vehicles that meet the requirements of the surveyed users. At the same time, $57.2 \%$ of carriers took adequate measures when the vehicles and equipment offered did not meet the requirements of consumers. Some $14.7 \%$ were not satisfied with the technical condition and cleanliness of vehicles used in the transportation of goods, and $28.6 \%$ remain neutral in their response.

In the third group of questions, users of transport services determined the extent to which they were satisfied with transport services over the past 12 months with respect to the following quality parameters:

- Matching the proposed transport solutions to your needs;

- Efficient coordination in meeting your delivery needs;

- Offering competitive transport services compared to other transport operators;

- Time for processing freight requests.

From the answers given, as to how satisfied they are with the service of transport companies, users of transport services draw the following conclusions:

- A small number of users were dissatisfied with the service during the last 12 months. Some 3.6\% remained deceived by the proposed transport solutions.

- Some $7.2 \%$ were not satisfied with the coordination in meeting their needs, and that other carriers offer more competitive services.

- To a large extent there is no surprise in the responses of consumers, most of them are satisfied with their service. This shows that in general consumers of transport services are conservative in their choice of carrier and, to change their decision, carriers need to make more efforts to offer more competitive conditions. 
In the group of issues related to the degree $\mid$ The results of the responses of the transport of satisfaction with respect to the proposed prices and pricing of their transportation. 3 and figure 4.
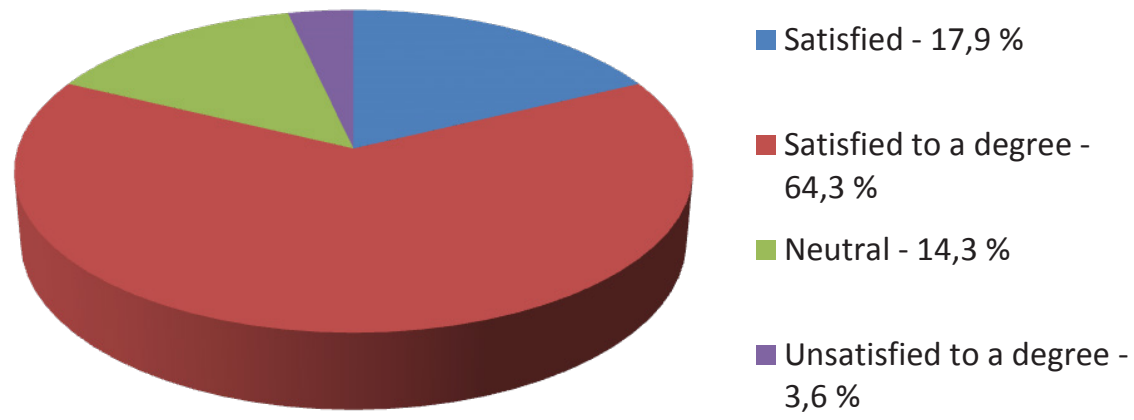

Figure 2. Distribution of respondent's responses regarding satisfaction with the proposed price.

With regard to the prices offered for additional services, the results are shown in figure 3 .

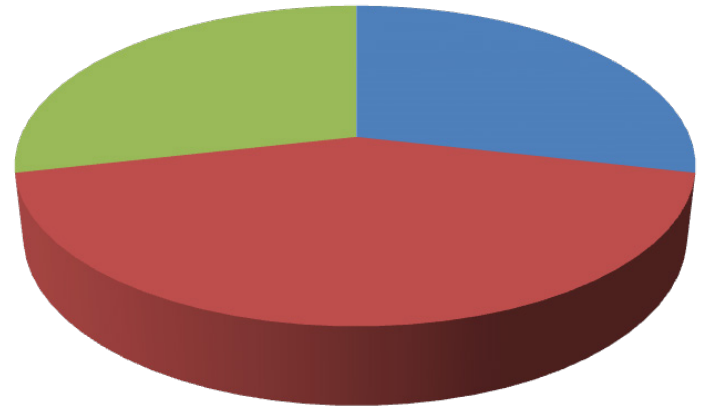

- Satisfied - 28,6 \%

Satisfied to a degree - 28,6

$\%$

Neutral - 28,6 \%

Figure 3. Distribution of respondents ' responses regarding satisfaction with the proposed price for additional services provided.

As to how satisfied the users of transport | when they were not accurately determined, services were when they had to adjust prices 1 the results were presented in figure 4 .

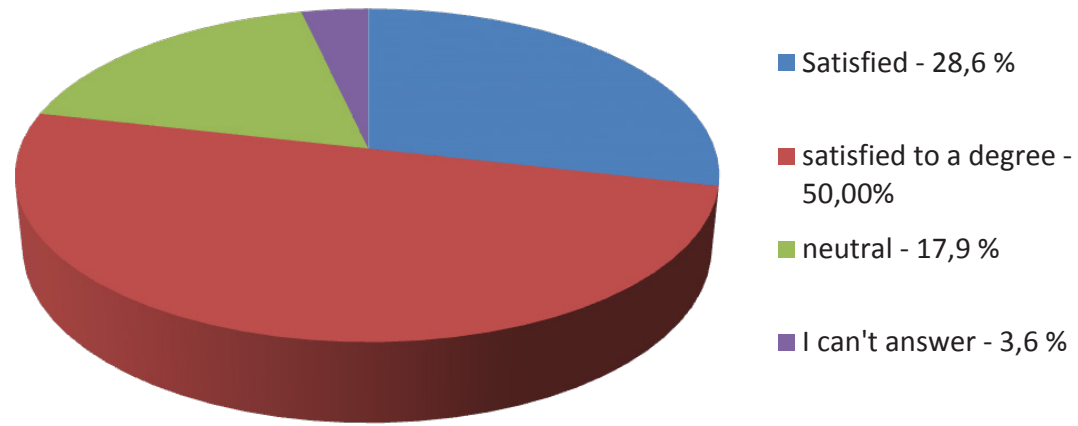

Figure 4. Distribution of respondents ' satisfaction responses when they had to adjust prices for their inaccurate definition. 


\section{Articles}

Analyzing the results of the group we found that there is quite declared conservatism of transport service's clients in terms of their choice of carrier and in relation to service, as well as the cost of transport service, a very large part is satisfied. This indicates that the users of transport services are, at their choice, largely informed and able to make adequate decisions according to their needs. This is confirmed by the fact that the cost of transport service is one of the three most important criteria when choosing a carrier.

In the next group of questions (the fifth group), the surveyed users of transport services determined the degree of satisfaction with their declared procedures and the payment of benefits for the following quality parameters:

- Effectiveness of measures and actions to prevent damage to the cargo during transportation;

- Timely solution of advertising claims for losses and damages;

- Access to information and help staff to resolve advertising claims.

Summarizing the answers of respondents in this group of questions and analyzing the results, we can draw the following conclusions:

- only $3.6 \%$ of users of transport services are dissatisfied with the measures taken by carriers to prevent damage. This shows that to a very large extent carriers are responsible for their activities;

- $57.1 \%$ of the carriers in time decide advertising claims;

- at the same time, $40 \%$ provide and help in resolving these claims;

- at the other pole, $10.7 \%$ of carriers do not provide any assistance in solving advertising requirements.
The next group (sixth) of questions covers how satisfied the users of transport services are, rather than serving their company with regard to communication and discussion of issues concerning them as consumers, and how transport companies, through innovation and creativity, foresee their needs as customers.

When analyzing the responses provided by the respondents, it seems that the transport companies are very much satisfied or meet the requirements and interests of customers and maintain good communication with them. At the same time, $14.3 \%$ do not offer any innovative and creative solutions to predict customer needs. Only $21.4 \%$ of users of transport services were satisfied with the proposed creativity of carriers, $32.1 \%$ to some extent satisfied, and $28.6 \%$ remain neutral in their response. All this can be one of the directions to break the conservative choice of transport services when choosing a carrier.

To the question "in comparison with other transport operators, how would you assess the service of the transport company" (figure 5). More than $32 \%$ of the surveyed users of transport services prefer to use the services of the same company. Some $42.9 \%$ define the service of transport companies as one and the same, they do not have a leading transport company, which can be used constantly. Another $21.4 \%$ of respondents determine the use of only one carrier, because they evaluate its activities as the best ones compared to other firms in the market and are reluctant to change it. Some $3.6 \%$ of respondents are not satisfied with the level offered by transport companies or have not yet found a suitable company. 


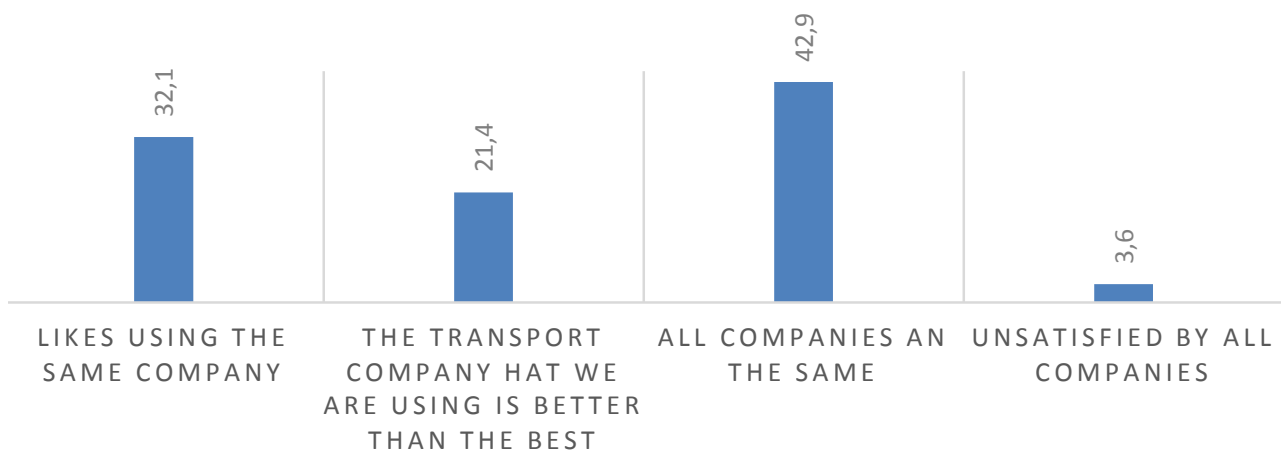

Figure 5. Distribution of respondents ' answers to the question "In comparison with other transport operators how would you rate the service of the transport company"

By analyzing the respondents' answers given above (seven groups of questions), the following generalizations can be made, to a large extent (53.5\%) the service offered by transport companies that meet the requirements of users of transport services, and they are reluctant to replace their main carrier. This is confirmed by the fact that more than $40 \%$ of respondents are to some extent satisfied with the prices offered during transportation and more than $32 \%$ are satisfied with innovation and creativity in their service. At the opposite pole are $42.9 \%$, for which all companies are the same in terms of the quality of services offered and 3.6\%, which determine the quality as unsatisfactory. In confirmation of this also more than $28 \%$ of respondents as neutral from the point of view of prices, and from the point of view of creativity and innovation, which is offered by transport operators.

All this can give us a reason to recommend transport operators to first develop strategies to improve customer service that can count on no small potential customers (more than 40\%) who do not have a core service company and, secondly, guidelines for improvement can be in making more creative and innovative decisions when developing their marketing concepts.

Figure 6, figure 7 and figure 8 respectively present the results in terms of which is the most important criterion according to the users of transport services when choosing a carrier.

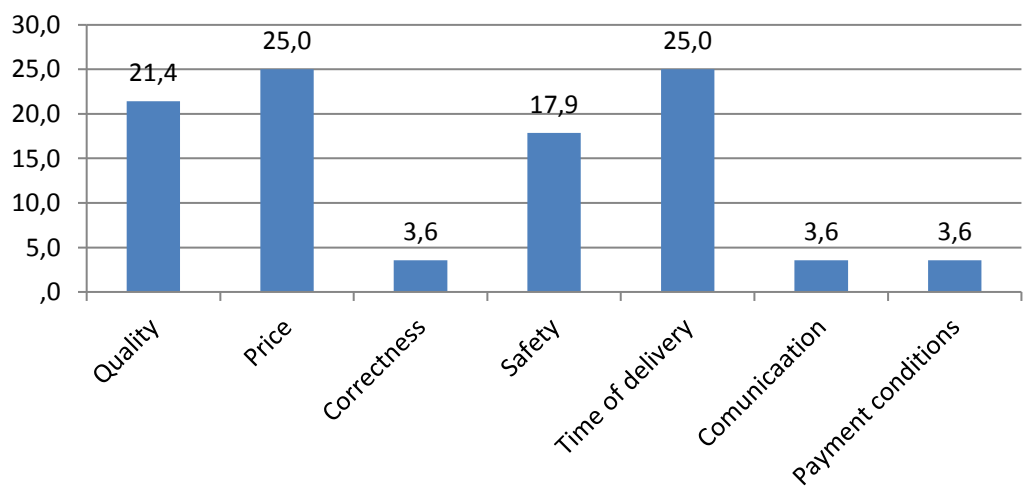

Figure 6. Criteria mentioned first by the respondents -\% 


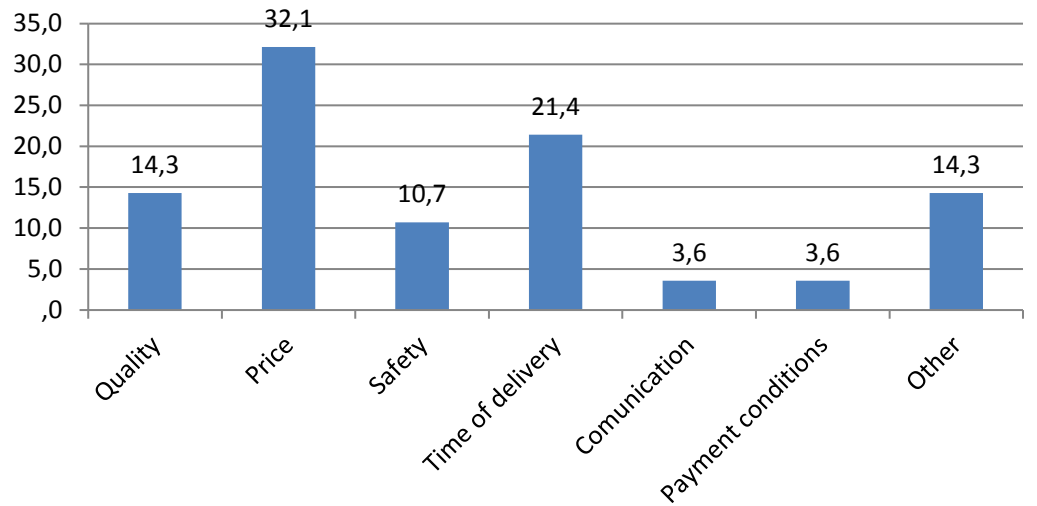

Figure 7. Criteria mentioned in second place by the respondents - \%

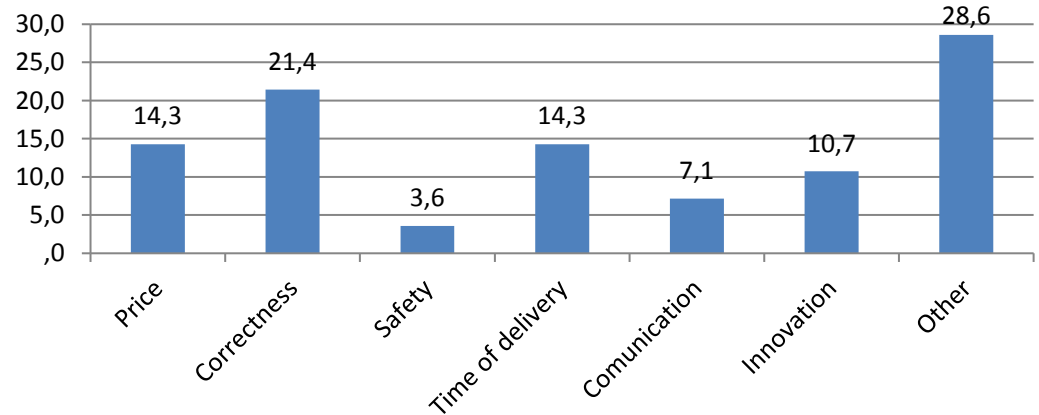

Figure 8. Criteria mentioned in third place of the respondents - \%

Users of transport services often primarily set delivery time (speed, flexibility) and price more than $25 \%$, and quality (good service) - $21.4 \%$ - as the most important criteria when choosing a carrier. Secondly, the importance of users again put the cost of transport service $-32.1 \%$, speed and quality as important criteria in their choice. Third, loyalty is defined as an important criterion. For users of transport services, delivery time, quality of transport services and, last but not least, the cost of delivery are the most important criteria when choosing a transport operator. To improve their competitiveness transport companies largely need to revise their strategies to pay attention to the criteria specified by users to find their competitive advantage.

\section{Conclusion}

As a result of the study, observations were made among users of transport services regarding their degree of satisfaction with the transport services offered on the market. In order for the results to serve as a benchmark for transport companies to improve their competitiveness, and further develop their market and management strategies, the following conclusions can be drawn:

- more than $40 \%$ of users of transport services do not constantly use the services of the same carrier;

- when choosing a carrier, users of transport services are conservative in their decisions;

- users of transport services make their decisions when they are fully informed, 


\section{Articles}

which allows them to make adequate decisions for their needs;

- the use of creative and innovative solutions to predict the needs of users of transport services can be one of the directions for the destruction of conservatism in the selection of the carrier;

- delivery time (speed, flexibility), price and quality of the offered transport service are the most important criteria when choosing a carrier;

One of the most important conclusions is that transport companies constantly have to pay more attention to the requirements for the ability to declare the necessary and equipped vehicles to meet customer requirements, as well as the vehicles' cleanliness and good technical condition, where there was not a small percentage of dissatisfaction among respondents. At the same time, the importance of these requirements for users of transport services was also confirmed by the correlation analysis. Issues related to the used transport equipment and vehicles over the past 12 months were found to be in a particularly strong correlation from questions group 1.3.4.5.6. and 7, which indicates that they change strongly influences all the others.

In general, the correlation is high between different groups of issues, indicating that each aspect of the transport companies has a significant impact on the other.

The following recommendations may be considered for future research:

- survey results can be updated or deepened in future studies;

- interest in the future may be a more indepth study of issues related to combined transport, why users do not use them fully (only $39.3 \%$ are interested in the proposed possibilities of communication with other modes of transport and the
Consumer Assessment of the Quality of Transport Services and Guidelines to Increase Their Competitiveness

use of terminals) and the study of stability with respect to the carrier (how often you change the carrier).

This survey of customer satisfaction with the supply of transport services covers freight transport users. The nature of the questions and the analysis of the results can be very much used by other modes of transport, if necessary.

\section{References:}

Bruning E. R., Lockshin L., 1995. Fundamental Elements in the Definition of Organizational Competitiveness.

Dochev, Ivan, 2008, Konkurentosposobnost na firmite. - Sbornik $s$ dokladi: XIII praktikoprilozhna konferentsia. „Balgarskite industrialni firmi v obedinena Evropa“ s. 37

Gatovski, II., 2017, Guidelines Improved the quality of transport services by road. Spisanie Ikonomika I infrastruktura" broi 1112. s. $277-281$

Iliev J., 2011, "Osnovni termini izpolzvani v uchebnia process" Tom 1. Ikonomika A-H. izd. "Simolini 94". s. 452-453

McConnell C., Brue St.L., Flynn S.M., 2011. Economics: Principles, Problems, and Policies. The McGraw-Hill Series in Economics.

Porter M.E., 1988. Competitive Advantage: Creating and Sustaining Superior Performance.

Porter M.E., 1990. The competitive advantage of nations. Free Press, New York.

Porter M.E., 1996. What is strategy? Harvard Business Review, NovemberDecember, 61-78.

Robinson J., 1933. The Economics of Imperfect Competition. Macmillan, London.

Schwab K. (ed.), 2011. The Global Competitiveness Report 2011-2012. 
Articles

Skinner W., 1985. Manufacturing: The Formidable Competitive Weapon. Wiley, New York.

Smith A., 1933. The Wealth of Nations. http://www.bibliomania.com/2/1/65/112/ frameset.html [on-line document].

Sterev N., 2014, COMPETITIVE CHANGES OF FOOD PRODUCTION IN BULGARIA, ACTA Oeconomia 13 (1) 2014, pp. 109-122

Sterev N., 2014, Konkurenten profil na proizvoditelite na hrani $v$ Bulgaria, sp. Ikonomicheski izsledvania, bp.3/2014, str. 92-116

Velev M. et al., 2009, Ikonomika i konkurentosposobnost

predpriemacheskata deynost. Sofia. Informa intelekt.
Velikova E., 2011, Teoretikometodologicheski vaprosi na uelnes turizma. Sofia: Avangard Prima, s. 191.

Velikova, E., 2008, Individualization of the Hotel Service. Economics and Management. Faculty of Economics, SOUTH-WEST UNIVERSITY "NEOFIT RILSKI", BLAGOEVGRAD, vol. 4(2), pages 55-60.

Warf F., Stutz B., 2007, The World Economy: Resources, Location, Trade and Development $\left(5^{\text {th }}\right.$ ed.). Pearson, Upper Saddle River.

Yordanov D., 2013, „Razvitie i usavarshenstvane na transportnoto predpriemachestvo" disertatsionen trud, UNSS, Sofia. 2013 